\title{
RELOCATION OF BURIED MARKERS
}

\author{
By W. H. Mathews \\ (Department of Geological Sciences, University of British Columbia, Vancouver, British Columbia \\ V6T I W5, Canada)
}

\begin{abstract}
Success has been achieved in relocating wire netting, which was subsequently covered by a year's net accumulation of snow on Berendon Glacier. A signal produced by a wire loop tuned to respond to a $15 \mathrm{kHz}$ electromagnetic output was readily detected by a hand-held battery-powered electromagnetic detector. Sextant readings on fixed landmarks around the glacier aided in locating the search area.

RÉsumé. Recherche de repères enfouis. On a mené à bien la recherche d'un treillis métallique qui avait été ultérieurement recouvert par l'accumulation nette d'une année de neige sur le névé du Berendon Glacier. Un signal produit par une maille métallique accordée pour répondre à une excitation électromagnétique de $15 \mathrm{kHz}$ a été facilement détecté par un détecteur électromagnétique alimenté par une batterie portative. Des lectures au sextent sur des marques fixes autour du glacier avaient aidé à localizer la zone de recherche.

Zusammenfassung. Wiederauffinden verschwundener Markierungen. Ein Drahtgeflecht, das von der NettoSchneeakkumulation auf dem Berendon-Firn bedeckt war, konnte mit Erfolg wiederentdeckt werden. Das Signal einer Drahtschleife, die auf Resonanz mit einem elektromagnetischen Sender von $15 \mathrm{kHz}$ eingestellt war, liess sich ohne weiteres mit einem tragbaren, batteriegespeisten E-M-Detektor empfangen. SextentMessungen nach festen Landmarken in Gletschernähe führten zu einer Grobbestimmung des Suchgebietes.
\end{abstract}

THE problem of relocating a fixed marker which has become covered by snow or shifting sand, or has been deliberately buried to avoid interference by humans or machines, is now common. When the marker has been set on a glacier surface and moves horizontally with time as well as being buried, the problem of relocation is compounded. The following report outlines one successful technique, and some less successful methods, for solving this problem.

Mass-budget studies on Berendon Glacier in the northern Coast Mountains of British Columbia (Untersteiner and Nye, 1968; Fisher and Jones, 1971) have involved monitoring of net annual snow accumulation at several stations in the névé region using a sheet of wire netting ("chicken wire" with $2.5 \mathrm{~cm}$ openings in sheets $\mathrm{I} \mathrm{m}$ by $2 \mathrm{~m}$ ) to mark the surface each summer at the end of the melting period. If the site can be relocated a year later, the depth of snow which has accumulated on the netting can be determined with the use of a Mount Rose snow corer. The netting is normally felt when the cutting edge of the corer makes contact with it, and the corer can be driven sharply through the netting so that a fragment of the wire is incorporated in the snow core. In the initial studies on Berendon Glacier the stations were marked with a $6 \mathrm{~m}$ length of drill casing, set upright in the snow with $4 \mathrm{~m}$ protruding, a measured distance to one side of the netting. Unless net accumulation had been very great, the upper end of the casing would be seen protruding above the snow at the end of the following summer.

Problems arose where snow accumulation was excessive or sinking of the drill casing through the pack had occurred so that no pipe was protruding at the time of search. On one such occasion a magnetometer was used successfully in locating the top of the casing, then still covered by about one meter of snow, although the time spent in levelling the magnetometer and observing field strength at points on a $1.5 \mathrm{~m}$ grid required the search area to be of limited size and well located. Use of powerful magnets added to the pipe to enhance the magnetic signal helped detection in later years, and indeed, on one occasion, permitted of the relocation of a toppled pipe with the aid of only a Brunton compass.

The expense of providing and transporting heavy drill casing by helicopter to the sites on the névé proved, however, to be excessive, and slender water pipe or wooden poles all too commonly toppled or broke during early winter storms.

Signals detectable with EM (electromagnetic) instruments were also considered. The first signal to be tried consisted simply of a single-strand heavy-gauge copper wire laid in a continuous circular loop about $5 \mathrm{~m}$ in radius around the wire netting. This was to be detected with an electromagnet reconnaissance unit consisting of a transmitting coil $\mathrm{I} \mathrm{m}$ in diameter slung horizontally about one searcher, and a similar receiving coil about the second searcher separated from the first by roo $\mathrm{m}$ of cable. This apparatus proved to be altogether too unwieldy especially when both operators had to negotiate crevasses. New developments, however, solved this difficulty by providing a small EM detector consisting of a transmitter and receiver at opposite ends of a small portable frame. Such an 
instrument* can be less than I m long and weigh only I. $35 \mathrm{~kg}$. A "tuned loop", consisting of a heavygauge insulated cable coupled to a condenser of appropriate characteristics so as to resonate in tune with the $15 \mathrm{kHz}$ transmitter provides a powerful signal for the receiver. Such a loop can weigh as little as $0.97 \mathrm{~kg}$.

Field tests were run in 1974 and 1975 . In 1974 three tuned loops were laid out at each of three sites on South Berendon névé. The wire netting was centrally located within $3 \mathrm{~m}$ diameter tuned loops. Locations were established by means of angles measured with an $8 \mathrm{~cm}$ box sextant between at least two pairs of well-defined landmarks on the exposed rocks of the valley walls, which lay from as little as $0.4 \mathrm{~km}$ to as much as $2.4 \mathrm{~km}$ away. Sketches and ground photographs were also taken to help identify landmarks and to facilitate return to the same points next year. In 1975 we returned to the sites, maneuvering across the snow until new sextant angles corresponded within a few minutes to those of the previous year. This permitted relocation to within about $10 \mathrm{~m}$ of the former sites in about $10-20$ min. After shifting directly down-glacier a distance equal to the estimated annual surface movement, we began a search with the EM instrument. Within as little as 2 min in one case and as much as $30 \mathrm{~min}$ in another (where the sextant fixes had been less carefully undertaken) an EM anomaly was located. The search pattern consisted of walking slowly in parallel tracks about $2 \mathrm{~m}$ apart (thus covering the area at a rate of about 0.4 ha per hour) while watching the instrument for any indication of an anomaly. Clearly in the interests of time, the centre of the search pattern should be located within a few tens of meters of the hidden signal. The anomaly, when intersected, provided an unmistakeable response with the tuned loop buried in wet firn as much as $4 \mathrm{~m}$ below the instrument, and the manufacturer's prediction that the signal would still be recognizable buried to a depth of $7 \mathrm{~m}$ seems fully justified. The anomaly proved to be sharply defined at the snow surface, roughly circular about $5 \mathrm{~m}$ in diameter, somewhat greater across than the loop itself. Two traverses of the anomaly at right angles to one another defined 4 points on its periphery, and in each case a core at the center of the anomaly brought up part of the wire netting.

The merits of this last system as an aid to mass-budget studies, among other things, is the ready portability of both signals and detector, the clear definition of the anomaly produced by the signal, particularly on snowfields where no other signal sources are to be expected, and the speed with which a search can be undertaken. The costs are significant, particularly for the detector, but this, apart for replacement of batteries, should require little or no maintenance over the years. Tuned loops are themselves not inexpensive but can serve to mark a station for several years, depending on rates of burial. If burial is shallow they may even be recoverable. The $>7 \mathrm{~m}$ limit of detectability in firn snow should be no less in dry snow or sand and a somewhat greater range could be expected with loops of larger diameter. The lifetime of the loops buried in a wet environment has not yet been reached. A portable sextant is indispensable for quick relocation but is again useable for many years on this as well as on other tasks. The Mount Rose corer, normally available to anyone undertaking mass budgets, is the most cumbersome item required.

\section{AGKNOWLEDGEMENTS}

For technical assistance in developing this method I am particularly indebted to Dr A. A. Brant of Newmont Exploration Ltd; the suggestion of wire netting as a means of marking the summer surfaces stems from Peter Kasser of the Swiss E.T.H. Support in the field tests has been provided by Granduc Operating Company and by the Glaciology Division, Environment Canada.

MS. received 3 March 1976

\section{REFERENCES}

Fisher, D. A., and Jones, S. J. 1971. The possible future behaviour of Berendon Glacier, Canada-a further study. Journal of Glaciology, Vol. 10, No. 58, p. 85-92.

Untersteiner, N., and Nye, J. F. 1968. Computations of the possible future behaviour of Berendon Glacier, Canada. Fournal of Glaciology, Vol. 7, No. 50, p. 205-13.

* The EM ${ }_{1} 5$ MK $_{2}$ produced by Geonics Limited, Toronto, Ontario. It has been estimated by the manufacturer that with the EM ${ }_{5} \mathrm{MK}_{2}$ instrument, fitted with a quadrature response, the tuned loop could be detected at a depth of at least $7 \mathrm{~m}$. Costs in 1976 in Canadian dollars were $\$ 940$ for the instrument, an additional $\$ 200$ for the quadrature response, and tuned loops at $\$ 60$ each. 